\title{
Crossbreeding locally adapted hair sheep to improve productivity and meat quality
}

\author{
Juliano Issakowicz ${ }^{1 *}$, Ana Claudia Koki Sampaio Issakowicz ${ }^{1}$, Mauro Sartori Bueno ${ }^{2}$ Ricardo Lopes Dias da Costa ${ }^{2}$, Andre Torres \\ Geraldo ${ }^{2}$, Adibe Luiz Abdalla ${ }^{1}$, Concepta McManus ${ }^{3}$, Helder Louvandini ${ }^{1}$
}

IUniversity of São Paulo/CENA - NAPTISA, Av. Centenário, 303 - 13416-000 - Piracicaba, SP - Brazil.

${ }^{2}$ Agency Paulista Agribusiness Technology/Animal Science Institute, R. Heitor Penteado, 56 - 13460-000 - Nova

Odessa, SP - Brazil.

3University of Brasilia/Institute of Biology, Campus

Universitário Darcy Ribeiro - 70910-900 - Brasilia, DF -

Brazil.

*Corresponding author <issakowicz@zootecnista.com.br>

Edited by: Paulo Cesar Sentelhas

Received July 11, 2016

Accepted April 09, 2017
ABSTRACT: The use of lambs from crossing of local with specialized sheep breeds for meat production may lead to higher meat deposition and a smaller fat amount in the carcass, with a more adequate nutritional profile for human consumption. This study investigated the performance, carcass and meat characteristics of lambs from the Morada Nova and Santa Inês locally adapted hair breeds and crosses between Dorper $\times$ Morada Nova and Dorper $\times$ Santa Inês slaughtered at approximately $35 \mathrm{~kg}$. Morada Nova lambs showed lower $(p<0.05)$ performance compared to the other genetic groups resulting in a higher age at slaughter $(p<0.05)$. Crossbred Dorper $\times$ Santa Inês and Dorper $\times$ Morada Nova lambs showed better characteristics for meat production with better $(p<0.05)$ conformation as well as leg and carcass compacteness index. Dorper $\times$ Santa Inês have a fatty acid profile that is more suitable for human consumption than Dorper $x$ Morada Nova lambs do $(p<0.05)$; however, both had lower $(p<0.05)$ intramuscular lipid content (as measured by ether extract levels from Longíssimus lumborum) compared with purebred lambs. Therefore, when the objective is to obtain lean meat, with improved nutritional profile to reduce risks of cardiovascular disease, the use of breeds and crosses that reduce animal slaughter age, such as the $1 / 2$ Dorper $\times 1 / 2$ Santa Inês crossbred, is an interesting alternative.

Keywords: locally adapted Brazilian breeds, breeding, fatty acid profile, quality meat, terminal sire breeds

\section{Introduction}

The efficiency of sheep production depends largely on growth characteristics of lambs. Production capacity of sheep to meet market demands can be improved by using breeds that are more adapted to the production system and exploring desirable characteristics of each breed (McManus et al., 2010).

Santa Inês (SI) is the most popular breed in Brazil distributed throughout the country (McManus et al., 2014). In Brazil, this breed has been used both for the production of purebred lambs as well as crosses for early slaughter (McManus et al., 2010). Morada Nova (MN) may be an alternative breed, as it is hardy but has lower adult weight, which can lead to greater number of animals per area and increase productivity per unit of space (Gomes et al., 2013; Issakowicz et al., 2016). Studies have shown that MN breed shows good maternal ability, prolificacy, nonexistent reproductive seasonality and good adaptation to the tropical environment, all useful characteristics in a maternal breed (McManus et al., 2014; Issakowicz et al., 2016).

However, the poor performance of its purebred lambs limits its use in intensive meat production systems. Crossbreeding of this breed with terminal sire breeds can improve performance characteristics in lambs. For this reason, sheep farmers have implemented crossbreeding of locally adapted animals with enhanced exotic genotypes (Dorper, for example) to improve the genetic potential of these animals. However, little information is available on lambs from Dorper sheep crossed with local Brazilian breeds in intensive production systems.

Dorper (D) is a breed originated in South Africa, a synthetic meat-type breed created from the Dorset and Black Head Persian breeds, widely used in crosses with native breeds (Milne, 2000; Teklebrhan et al., 2014), for their growth potential and carcass quality (Kosgey et al., 2008; Kariuki et al., 2010).

This study evaluated the performance, carcass and meat characteristics of Morada Nova (MN), Santa Inês (SI) and crossbred Dorper $\times$ Morada Nova (DM) and Dorper $\times$ Santa Inês (DS) lambs finished in feedlot.

\section{Materials and Methods}

The experiment was conducted in São Paulo state, southeastern Brazil $\left(22^{\circ} 42^{\prime} \mathrm{S}\right.$ and $47^{\circ} 18^{\prime} \mathrm{W}$, altitute 570 $\mathrm{m})$. This study was approved by the Commission of Ethics for the Use of Animals in Experimentation at the Institute of Animal Science (Protocol No. 168/2013).

\section{Animals, feeds and management}

Eight intact lambs, approximately 70 days old, from each of four genotypes, two native hair sheep breeds (Morada Nova, Santa Inês) and crosses of these with Dorper were used in this study. To eliminate the effect of the rams, lambs in each genetic group were selected from different rams.

During the lactation period, the lambs remained with their dams until 60 days of age with concentrate ration and corn silage ad libitum and then were housed in in- 
dividual pens measuring $1.2 \mathrm{~m}^{2}$ with a suspended wooden slat floor, feeders and water. Before starting the measurements, a 10-day adaptation for diets and facilities was carried out. The animals were fed two meals a day $108 \mathrm{~h} 00$ and $15 \mathrm{~h} 00$ ). The diets were composed of corn silage (40 \%) and concentrate $(60 \%)$. The chemical composition of corn silage and concentrate are presented in Table 1.

\section{Growth performance}

The offered food and orts were weighed daily and the daily dry matter intake (DMI) calculated. This variable was expressed as grams per day $\left(\mathrm{g} \mathrm{d}^{-1}\right)$, as a proportion of metabolic weight (g DM/kg LW $\left.{ }^{0.75}\right)$, as well as percentage of live weight (\% LW).

Daily live weight gains (DLWG) were calculated by weighing animals at the beginning and end of the experimental period (when the animals reached $35 \mathrm{~kg}$ approximately) and at $14 \mathrm{~d}$ intervals in the morning, before feeding. Feed conversion (FC) was estimated as DM intake (kg intake/daily live weight gain (kg).

\section{Carcass and meat quality}

At end of the trial, the animals were fasted from solid food for $12 \mathrm{~h}$, weighed (slaughter weight) and slaughtered. After removing and weighing the non-carcass components, carcasses were weighed (hot carcass weight - HCW) and refrigerated for $24 \mathrm{~h}$ at a temperature of $2-4{ }^{\circ} \mathrm{C}$ (cold carcass weight - CCW). The hot (HCY) and cold (CCY) carcass yields were obtained as follows: (HCW/slaughter weight) * 100 and (CCW/ slaughter weight) $* 100$, respectively. Carcass fat cover score (CFCS) and carcass conformation score (CCS) were performed through visual appreciation according to Issakowicz et al. (2013).

Table 1 - Ingredients of concentrate and chemical composition of corn silage and concentrate fed to fattening lambs.

\begin{tabular}{|c|c|c|}
\hline \multirow{2}{*}{ Ingredients } & Concentrate & Corn \\
\hline & Ingredient proportion & \\
\hline \multicolumn{3}{|c|}{$\%$} \\
\hline Corn & 71.4 & - \\
\hline Soybean & 25.0 & - \\
\hline Mineral Mixture ${ }^{*}$ & 1.3 & - \\
\hline Sodium Chloride & 0.7 & - \\
\hline Limestone & 1.6 & - \\
\hline \multicolumn{3}{|c|}{ Chemical composition (\%) ** } \\
\hline Dry matter & 84.4 & 22.1 \\
\hline Crude protein & 22.3 & 7.9 \\
\hline Neutral detergent fiber & 20.3 & 62.6 \\
\hline Acid detergent fiber & 3.82 & 31.9 \\
\hline Hemicellulose & 16.5 & 30.7 \\
\hline Ether extract & 2.60 & 3.2 \\
\hline Mineral matter & 6.20 & 5.8 \\
\hline \multicolumn{3}{|c|}{$\begin{array}{l}{ }^{*} \text { Composition of product: Calcium } 120 \mathrm{~g} \mathrm{~kg}^{-1} \text {, Phosphorus } 87 \mathrm{~g} \mathrm{~kg}^{-1} \text {, Sodium } \\
147 \mathrm{~g} \mathrm{~kg}^{-1} \text {, Sulfur } 18 \mathrm{~g} \mathrm{~kg}^{-1} \text {, Copper } 590 \mathrm{mg} \mathrm{kg}{ }^{-1} \text {, Cobalt } 40 \mathrm{mg} \mathrm{kg} \text {, } \\
\text { Chromium } 20 \mathrm{mg} \mathrm{kg} \text {, Iron } 1800 \mathrm{mg} \mathrm{kg} \text {, lodine } 80 \mathrm{mg} \mathrm{kg}^{-1} \text {, Manganese } \\
1300 \mathrm{mg} \mathrm{kg}^{-1} \text {, Selenium } 15 \mathrm{mg} \mathrm{kg-1} \text {, Zinc } 3800 \mathrm{mg} \mathrm{kg}^{-1} \text {, Molybdenum } 300 \\
\mathrm{mg} \mathrm{kg}^{-1} \text {, and Fluorine (max.) } 870 \mathrm{mg} \mathrm{kg}^{-1} \text {; * Percentage at } 100 \% \text { dry matter. }\end{array}$} \\
\hline
\end{tabular}

The final $\mathrm{pH}(\mathrm{pH} 24)$ was mensured on the Semimembranosus muscle at $24 \mathrm{~h}$ after slaughter with the aid of a portable pHmeter.

The carcasses were sectioned into two half-carcasses and the left half was divided into commercial cuts (Figure 1), which were weighed and their proportion of the half carcass determined.

On the right half of the carcass, a transverse cut was taken between the $12^{\text {th }}$ and $13^{\text {th }}$ ribs to free the $12^{\text {th }}$ rib. The area of the Longissimus lumborum muscle was measured using a transparent standardized grid 10.5 $\mathrm{cm}^{2} /$ cell) giving the RYA (rib eye area), height and width of the loin. The $12^{\text {th }}$ rib was then weighed and tissues were dissected into muscle, bone and fat, according to methodology adapted from Hankins and Howe (1946). The $12^{\text {th }}$ rib tissues were minced together, homogenated and freeze dried for chemical composition analysis acording to AOAC (1995) procedures to determine dry matter (DM), crude protein (CP), ether extract (EE) and mineral matter (MM) content. The chemical composition of the Longissimus lumborum muscle was performed in the same manner as for the $12^{\text {th }}$ rib tissue.

The carcass compactness index (CCI) was calculated through the relation of cold carcass weight / internal carcass length and the leg compactness index (LCI) by the ratio of leg weight and its respective length. The internal carcass length - IL (maximum distance between the front edge of the ischial pubic symphysis and the front edge of the first rib at its midpoint) and leg length - LL (shortest distance from the perineum to the edge of tarsometatarsal articulation) were taken using a metric tape after the carcass cooled.

\section{Fatty acid profile analysis}

Samples from the Longíssimus lumborum were used for the analysis of fatty acid profile. Lipids were extracted from the muscle in accordance with procedures established by Folch et al. (1957) and were methylated according to Hara and Radin (1978). The transmethylated samples were analyzed with a gas chromatograph (model Focus CG-Finnigan, Thermo Finnigan) with a flame-ionization detector and a capillary column (CP-Sil 88) measuring $100 \mathrm{~m} \times 0.25 \mathrm{~mm}$

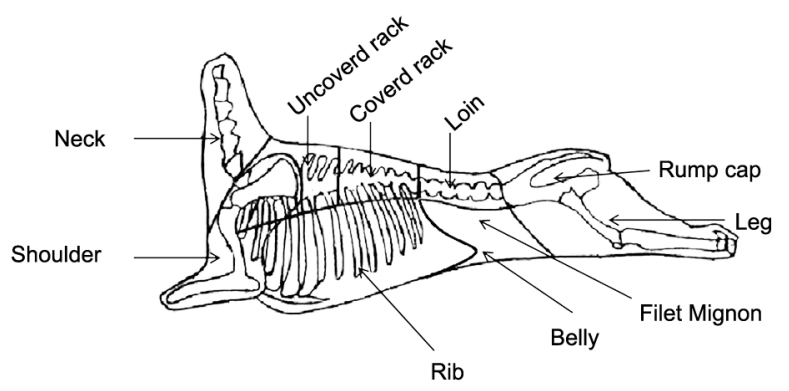

Figure 1 - Meat cuts of the left half of the carcasses. Adapted from Santos et al. (2001). 
i.d., with a thickness of $0.20 \mu \mathrm{m}$. Hydrogen was used as the carrier gas at a flow rate of $1.8 \mathrm{~mL} \mathrm{~min}^{-1}$. The initial temperature of the oven was $70{ }^{\circ} \mathrm{C}$ and was increased by $13{ }^{\circ} \mathrm{C} / \mathrm{min}$ to $175^{\circ} \mathrm{C}$, and kept for $27 \mathrm{~min}$. The temperature was then increased by $4{ }^{\circ} \mathrm{C} / \mathrm{min}$ to $215{ }^{\circ} \mathrm{C}$, where it was kept for $9 \mathrm{~min}$, followed by another increase by $7{ }^{\circ} \mathrm{C} / \mathrm{min}$ to $230{ }^{\circ} \mathrm{C}$, where it remained for 5 min. The temperature of the injector was $250{ }^{\circ} \mathrm{C}$, and the temperature of the detector was $300{ }^{\circ} \mathrm{C}$. Identification of the fatty acids was carried out by comparison of the retention times with fatty acid standards of from butter, and the percentage of fatty acids was obtained by means of Chromquest 4.1 software.

The amount of desirable fatty acids (DFA) was determined as the total of mono unsaturated fatty acids (MUFA), polyunsaturated fatty acids (PUFA) and stearic acid according to Landim et al. (2011). The activities of the $\Delta 9$-desaturase (C16 and $\mathrm{C} 18$ ) and elongase enzymes were determined as described by De Smet et al. (2004). The atherogenicity index (ATHERO) was calculated in accordance with Ulbricht and Southgate (1991). Calculations were performed as follows:

$\mathrm{DFA}=\mathrm{MUFA}+\mathrm{PUFA}+\mathrm{C} 18: 0$

$\Delta$ 9-desaturase $\mathrm{C} 16=100[(\mathrm{C} 16: 1$ cis-9)/ $(\mathrm{C} 16: 1$ cis-9 + C16:0)]

49-desaturase C18 = 100[(C18:1 cis-9)/(C18:1 cis-9 + C18:0)]

Elongase $=100[(\mathrm{C} 18: 0+\mathrm{C} 18: 1$ cis-9) $/(\mathrm{C} 16: 0+\mathrm{C} 16: 1$ cis-9 + C18:0 + C18:1 cis-9)]

ATHERO $=\left[\mathrm{C} 12: 0+\left(4^{*} \mathrm{C} 14: 0\right)+\mathrm{C} 16: 0\right] /(\Sigma \mathrm{SFA}+$ $\Sigma$ PUFA)

\section{Statistical analysis}

Data on performance, carcass characteristic and fatty acids were analyzed using the GLM procedure of statistical analysis software institute SAS (Statistical Analysis System v. 9.2, Cary, NC) with the genetic group as fixed effects and the initial weight as a covariant for the performance data and the final weight for the other characteristics. The model used was:

$Y_{i j k}=\mu+G_{i}+(I-I m)_{i j}+e_{i j k}$

where $\mu$ is the overall mean, $G_{i}$ is the fixed effect of the ith genetic group, $I$ is the initial weight of the jth animal in the ith genetic group, Im is the mean initial weight and $e_{i j k}$ is the random error associated with each observation. The effects of ram, type of birth (single or multiple), and slaughter day were removed from the statistical model because they did not affect any studied variable. The mean comparison was performed by the Tukey test with the mean corrected by least squares (pdiff instruction in SAS). Correlation (CORR procedure) and factor analysis (FACTOR procedure) were performed to verify the relationship between slaughter age and carcass characteristics. The discriminant analysis (DISCRIM procedure) was performed to verify the ability of data to classify the animal genetic group, and STEPDISC procedure to identify these traits.

\section{Results}

\section{Growth performance}

On the same diet (Table 1) the dry matter intake (DMI) was similar $(p>0.05)$ among genetic groups (Table 2). The crossbred (DS and DM) and Santa Inês (SI) lambs had similar $(p>0.05)$ daily live weight gains (DLWG) and feed conversion (FC), which were higher $(p<0.05)$ than that observed in Morada Nova lambs resulting in a reduction $(p<0.05)$ of slaughter age of the former animals.

\section{Carcass and meat quality}

Crossbred lambs (DS and DM) had higher ( $p<$ 0.05) conformation, leg and carcass compactness index, than observed in purebred lambs (SI and MN) (Table 3). No difference $(p>0.05)$ among groups was observed for $\mathrm{pH} 24$.

Table 2 - Mean \pm standard error of the performance variables from Morada Nova (MN), $1 / 2$ Dorper $\times 1 / 2$ Morada Nova (DM), Santa Inês (SI) and $1 / 2$ Dorper $\times 1 / 2$ Santa Ines (DS) lambs finished in feedlot.

\begin{tabular}{|c|c|c|c|c|}
\hline \multirow{2}{*}{ Variable } & \multicolumn{4}{|c|}{ Genetic Group } \\
\hline & DM & $\mathrm{MN}$ & DS & SI \\
\hline IBW (kg) & $16.1 \pm 1.0^{b}$ & $15.0 \pm 1.0^{\mathrm{b}}$ & $21.3 \pm 1.0^{\mathrm{a}}$ & $18.4 \pm 1.0^{\mathrm{ab}}$ \\
\hline FBW (kg) & $36.2 \pm 1.36$ & $33.1 \pm 1.46$ & $34.0 \pm 1.54$ & $35.3 \pm 1.33$ \\
\hline $\mathrm{DMI}\left(\mathrm{g} \mathrm{d}^{-1}\right)$ & $982 \pm 39$ & $866 \pm 42$ & $866 \pm 44$ & $950 \pm 38$ \\
\hline $\mathrm{DM}^{0.75}$ & $64.9 \pm 2.1$ & $62.3 \pm 2.2$ & $60.3 \pm 2.3$ & $64.6 \pm 2.0$ \\
\hline DMI \%LW & $2.62 \pm 0.08$ & $2.58 \pm 0.09$ & $2.48 \pm 0.10$ & $2.63 \pm 0.08$ \\
\hline DLWG $\left(\mathrm{g} \mathrm{d}^{-1}\right)$ & $233 \pm 14^{a}$ & $146 \pm 17^{b}$ & $229 \pm 19 a$ & $226 \pm 14^{a}$ \\
\hline FC (kg DMl / kg DLWG) & $4.17 \pm 0.25^{b}$ & $5.52 \pm 0.25^{a}$ & $4.02 \pm 0.28^{b}$ & $4.32 \pm 0.24^{b}$ \\
\hline Slaughter age (day) & $157 \pm 7.26^{b}$ & $186 \pm 7.26^{a}$ & $135 \pm 6.76^{b}$ & $154 \pm 7.26^{b}$ \\
\hline
\end{tabular}

Means in the same row followed by the same superscript letter do not differ significantly by the Tukey test $(p \leq 0.05)$; IBW = initial body weight; FBW = final body weight; DMl $\left.\right|^{0.75}=$ dry matter intake in grams DM / Weight $0.75 ; \mathrm{DMl} \% \mathrm{LW}=$ dry matter intake in $\%$ of body weight; DLWG = daily live weight gains; FC = feed conversion. 
Table 3 - Mean \pm standard error of the carcass characteristics from Morada Nova (MN), $1 / 2$ Dorper $\times 1 / 2$ Morada Nova (DM), Santa Inês (SI) and $1 / 2$ Dorper $\times 1 / 2$ Santa Ines (DS) lambs finished in feedlot.

\begin{tabular}{lcccc}
\hline \multirow{2}{*}{ Variable } & \multicolumn{4}{c}{ Genetic Group } \\
\cline { 2 - 5 } & DM & MN & DS & Sl \\
\hline Slaughter Weight (kg) & $35.6 \pm 1.37$ & $32.0 \pm 1.37$ & $35.4 \pm 1.37$ & $35.6 \pm 1.37$ \\
HCW (kg) & $16.9 \pm 0.28$ & $16.8 \pm 0.30$ & $17.1 \pm 0.28$ & $16.1 \pm 0.28$ \\
CCW (kg) & $16.4 \pm 0.27$ & $16.4 \pm 0.29$ & $16.7 \pm 0.27$ & $15.6 \pm 0.27$ \\
HCY (\%) & $48.7 \pm 0.82$ & $48.5 \pm 0.87$ & $49.4 \pm 0.81$ & $46.5 \pm 0.82$ \\
CCY (\%) & $47.5 \pm 0.8$ & $47.3 \pm 0.8$ & $48.0 \pm 0.8$ & $45.1 \pm 0.8$ \\
CCF (1-5) & $3.29 \pm 0.09^{\mathrm{a}}$ & $2.66 \pm 0.09^{\mathrm{b}}$ & $3.39 \pm 0.09^{\mathrm{a}}$ & $2.76 \pm 0.09^{\mathrm{b}}$ \\
CFCS (1-5) & $2.58 \pm 0.17$ & $2.30 \pm 0.17$ & $2.54 \pm 0.17$ & $2.59 \pm 0.17$ \\
LCl (kg cm $\left.{ }^{-1}\right)$ & $0.100 \pm 0.004^{\mathrm{a}}$ & $0.091 \pm 0.004^{\mathrm{b}}$ & $0.112 \pm 0.004^{\mathrm{a}}$ & $0.079 \pm 0.004^{\mathrm{b}}$ \\
CCl (kg cm l $\left.^{-1}\right)$ & $0.286 \pm 0.005^{\mathrm{a}}$ & $0.280 \pm 0.005^{\mathrm{b}}$ & $0.286 \pm 0.005^{\mathrm{a}}$ & $0.263 \pm 0.005^{\mathrm{b}}$ \\
$\mathrm{pH}_{24}$ & $5.42 \pm 0.12$ & $5.69 \pm 0.12$ & $5.61 \pm 0.12$ & $5.62 \pm 0.12$ \\
\hline
\end{tabular}

Means in the same row followed by the same superscript letter do not differ significantly by the Tukey test $(p \leq 0.05)$; HCW $=$ hot carcass weight; CCW = cold carcass weight; $\mathrm{HCY}=$ hot carcass yield; $\mathrm{CCY}=$ cold carcass yield; $\mathrm{CCF}=$ carcass conformation score; $\mathrm{CFCS}=$ carcass fat cover score; $\mathrm{LCl}=$ leg compactness index; $\mathrm{CCl}$ $=$ Carcass compactness index; $\mathrm{pH}_{24}=\mathrm{pH} 24 \mathrm{~h}$ after slaughter.

With the advancement of slaughter age, there were increases in the proportions of visceral fat $(\mathrm{r}=$ $0.39 ; p=0.01)$, inguinal fat $(\mathrm{r}=0.38 ; p=0.02)$ and renal fat $(\mathrm{r}=0.41 ; p=0.01)$ in the carcass. In addition, there was a reduction in higher priced cuts such as leg $(\mathrm{r}=-0.57 ; p=0.01)$, shoulder $(\mathrm{r}=-0.43 ; p=0.01)$, rump cap $(\mathrm{r}=-0.35 ; p=0.01)$, mignon $(\mathrm{r}=-0.55 ; p=$ $0.01)$ and an increase in the proportion of less valued cuts such as the neck $(\mathrm{r}=0.44 ; p=0.01)$. These relationships may be seen in the principal component analysis (PCA) (Figure 2) where the first component explained $37 \%$ of the variance between the traits studied.

The discriminant analysis using the proportion of commercial cuts and the leg compactness index, classified $88 \%$ of DS animals and $100 \%$ of the DM, MN and SI animals, in their respective genetic groups. The main variables that discriminated the groups were neck proportion $\left(R^{2}=0.57\right)$, shoulder proportion $\left(R^{2}=0.34\right)$, leg compactness $\left(\mathrm{R}^{2}=0.32\right)$ and the proportion of the belly $\left(\mathrm{R}^{2}=0.22\right)$.

The Longissimus lumborum dimensions, as well as the centesimal (dissection) and chemical composition of the $12^{\text {th }}$ rib are shown in Table 4 . Height, width and rib eye area (RYA) were higher $(p<0.05)$ in crossbred lambs (DS and DM), and there was no difference $(p>0.05)$ in mass (g) and proportion (\%) of bone, muscle and fat from purebreds in relation to crosses. This was probably due to high individual variation, which reflected in a high coefficient of variation found for these variables. A significant difference was observed in Muscle: Fat ratio, with DS lambs having greater $(p<0.05)$ value than the other groups.

In the chemical evaluation of $12^{\text {th }}$ rib, DS lambs had lower $(p<0.05) \mathrm{EE}$ content compared to the other groups, and Morada Nova lambs presented the highest values followed by SI, DM lambs. On the other hand, the Longissimus lumborum of crossbred lambs showed lower $(p<0.05)$ content of EE compared to purebred lambs (Table 4).

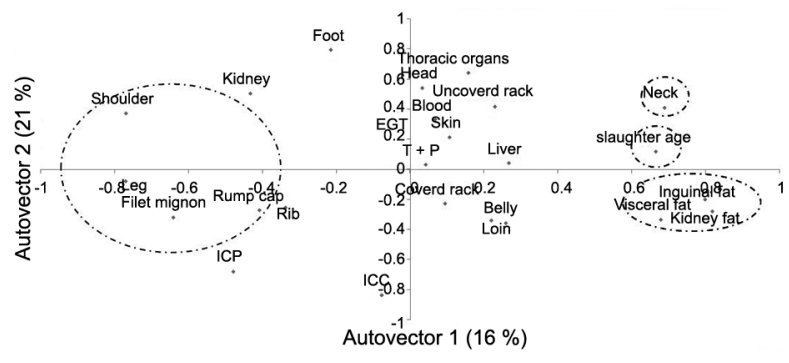

Figure 2 - First two principal components showing the relationship between the slaughter age and carcass characteristics. $T+P=$ Empty gastrointestinal tract.

\section{Fatty acid profile analysis}

The fatty acid profile of meat (Tables 5 and 6) shows that DS lambs had higher levels $(p<0.05)$ of essential fatty acids (n-3 and n-6) and polyunsaturated fatty acids such as linoleic (C18: 2C9C12), Arachidonic (C20: 4n6) and docosapentaenoic (C22: 5), compared to DM animals, contributing to the greater amount polyunsaturated acids (PUFA), higher PUFA: SFA ratio and better atherogenicity index ( $\mathrm{DS}=0.599 ; \mathrm{DM}=0.660)$.

The percentage of saturated fatty acids (SFA) did not differ $(p>0.05)$ between the groups, although significant variations $(p \leq 0.05)$ were observed for some saturated acids (C15:0, C15:0iso, C15:0anteiso, C17:0, C17:0iso), but they represent only a small proportion of the total SFA. The predominant saturated fatty acids were palmitic acid (C16: 0), followed by stearic acid (C18: 0), but these did not differ $(p>0.05)$ between genotypes. Of the monounsaturated fatty acids found in quantities greater than $0.05 \mathrm{~g} / 100 \mathrm{~g}$ fat, in all genetic groups studied, oleic acid (C18: 1C9) was the most prominent (approximately $40 \%$ ).

\section{Discussion}

Purebred MN lambs on the same diet (Table 1) showed lower performance compared to the other 
Table 4 - Mean \pm standard error of the loin dimensions and $12^{\text {th }}$ rib characteristics from Morada Nova (MN), $1 / 2$ Dorper $\times 1 / 2$ Morada Nova (DM), Santa Inês (SI) and 1/2 Dorper $\times 1 \frac{1}{2}$ Santa Ines (DS) lambs finished in feedlot.

\begin{tabular}{|c|c|c|c|c|}
\hline \multirow{2}{*}{ Variable } & \multicolumn{4}{|c|}{ Genetic Group } \\
\hline & DM & MN & DS & $\mathrm{SI}$ \\
\hline LoinHeight (cm) & $3.26 \pm 0.10^{a}$ & $2.88 \pm 0.10^{b}$ & $3.24 \pm 0.10^{a}$ & $2.77 \pm 0.10^{b}$ \\
\hline LoinWidth (cm) & $5.79 \pm 0.14^{\mathrm{ab}}$ & $5.58 \pm 0.15^{b}$ & $6.20 \pm 0.14^{a}$ & $5.46 \pm 0.14^{b}$ \\
\hline RYA $\left(\mathrm{cm}^{2}\right)$ & $15.2 \pm 0.66^{a}$ & $12.3 \pm 0.69^{b}$ & $15.5 \pm 0.66^{a}$ & $12.1 \pm 0.66^{b}$ \\
\hline Total tissue weight (g) & $96.0 \pm 4.22^{\mathrm{a}}$ & $95.5 \pm 4.45^{\mathrm{a}}$ & $87.0 \pm 4.20^{\mathrm{ab}}$ & $74.1 \pm 4.21^{\mathrm{b}}$ \\
\hline Muscle( g) & $52.0 \pm 2.73^{a}$ & $44.8 \pm 2.88^{\mathrm{ab}}$ & $48.9 \pm 2.72^{\mathrm{ab}}$ & $38.5 \pm 2.72^{b}$ \\
\hline Muscle $(\%)^{1}$ & $54.6 \pm 2.11^{\mathrm{ab}}$ & $47.4 \pm 2.22^{b}$ & $56.0 \pm 2.10^{\mathrm{a}}$ & $51.9 \pm 2.10^{\mathrm{ab}}$ \\
\hline Bone (g) & $16.6 \pm 2.09$ & $15.9 \pm 2.20$ & $19.9 \pm 2.08$ & $13.8 \pm 2.09$ \\
\hline Bone $(\%)^{1}$ & $17.0 \pm 1.84$ & $16.4 \pm 1.94$ & $22.7 \pm 1.83$ & $18.6 \pm 1.84$ \\
\hline Fat (g) & $27.2 \pm 2.04^{\mathrm{ab}}$ & $34.8 \pm 2.15^{\mathrm{a}}$ & $18.1 \pm 2.03^{c}$ & $21.6 \pm 2.04^{b c}$ \\
\hline Fat $(\%)^{1}$ & $28.3 \pm 2.07^{a b}$ & $36.1 \pm 2.18^{a}$ & $21.2 \pm 2.06^{b}$ & $29.4 \pm 2.06^{a}$ \\
\hline Muscle : Fat & $1.95 \pm 0.21^{\mathrm{b}}$ & $1.39 \pm 0.22^{\mathrm{b}}$ & $2.85 \pm 0.21^{\mathrm{a}}$ & $1.80 \pm 0.21^{\mathrm{b}}$ \\
\hline \multicolumn{5}{|c|}{ Chemical composition of the $12^{\text {th }}$ rib } \\
\hline$\overline{\mathrm{DM}}$ & $47.9 \pm 1.39^{a}$ & $52.9 \pm 1.47^{a}$ & $42.1 \pm 1.39^{b}$ & $48.7 \pm 1.39 a$ \\
\hline $\mathrm{CP}^{2}$ & $17.5 \pm 0.57^{a b}$ & $15.5 \pm 0.60^{b}$ & $18.7 \pm 0.57^{a}$ & $17.3 \pm 0.57^{\mathrm{ab}}$ \\
\hline $\mathrm{EE}^{2}$ & $25.7 \pm 1.38^{b}$ & $32.8 \pm 1.45^{\mathrm{a}}$ & $18.7 \pm 1.37 c$ & $26.7 \pm 1.38^{b}$ \\
\hline $\mathrm{MM}^{2}$ & $4.70 \pm 0.35$ & $4.55 \pm 0.37$ & $4.57 \pm 0.35$ & $4.68 \pm 0.35$ \\
\hline \multicolumn{5}{|c|}{ Chemical composition of Longissimus dorsi } \\
\hline$\overline{\mathrm{DM}}$ & $26.9 \pm 0.98$ & $30.1 \pm 1.03$ & $28.3 \pm 1.12$ & $28.6 \pm 0.98$ \\
\hline $\mathrm{CP}^{2}$ & $16.2 \pm 0.7$ & $17.4 \pm 0.7$ & $17.5 \pm 0.8$ & $17.5 \pm 0.7$ \\
\hline $\mathrm{EE}^{2}$ & $5.81 \pm 0.45^{b}$ & $7.74 \pm 0.44^{\mathrm{a}}$ & $5.76 \pm 0.48^{b}$ & $6.67 \pm 0.42^{\mathrm{a}}$ \\
\hline $\mathrm{MM}^{2}$ & $1.11 \pm 0.03$ & $1.17 \pm 0.03$ & $1.22 \pm 0.04$ & $1.18 \pm 0.04$ \\
\hline
\end{tabular}

protein; MM = mineral matter; $\mathrm{EE}=$ ether extract; ${ }^{1}$ Percent relative to the total weight of the $12^{\text {th }}$ rib; ${ }^{2}$ Percent on natural matter.

Table 5 - Least square means (standard error of mean) of overall fatty acid, ratios and indices of meat from Morada Nova (MN), $1 / 2$ Dorper $\times \frac{1}{2}$ Morada Nova (DM), Santa Inês (SI) and $1 / 2$ Dorper $\times$ $1 / 2$ Santa Inês (DS).

\begin{tabular}{lccccc}
\hline & DM & MN & DS & SI & SEM \\
\hline SFA & 45.847 & 45.896 & 45.316 & 47.869 & 1.193 \\
UFA & 53.520 & 53.565 & 54.015 & 51.551 & 1.916 \\
MUFA & 47.788 & 46.926 & 44.925 & 45.217 & 1.722 \\
PUFA & $5.732^{\mathrm{b}}$ & $6.639^{\mathrm{ab}}$ & $9.090^{\mathrm{a}}$ & $6.334^{\mathrm{b}}$ & 0.739 \\
$\mathrm{n}-6$ & $1.432^{\mathrm{b}}$ & $1.818^{\mathrm{ab}}$ & $2.724^{\mathrm{a}}$ & $1.81^{\mathrm{ab}}$ & 0.297 \\
$\mathrm{n}-3$ & $0.159^{\mathrm{b}}$ & $0.17^{\mathrm{ab}}$ & $0.264^{\mathrm{a}}$ & $0.199^{\mathrm{ab}}$ & 0.027 \\
$\mathrm{n}-6: \mathrm{n}-3$ & 9.020 & 10.914 & 10.348 & 9.058 & 0.708 \\
UFA:SFA & 1.166 & 1.195 & 1.194 & 1.120 & 0.074 \\
PUFA:SFA & $0.124^{\mathrm{b}}$ & $0.149^{\mathrm{ab}}$ & $0.202^{\mathrm{a}}$ & $0.137^{\mathrm{ab}}$ & 0.019 \\
DFA & 71.029 & 68.669 & 71.895 & 70.025 & 1.141 \\
AD9 C16 & 8.251 & 7.987 & 8.059 & 7.342 & 0.492 \\
AD9C18 & 70.220 & 72.625 & 67.925 & 67.595 & 2.021 \\
ELONGASE & 69.614 & 65.856 & 69.455 & 68.173 & 1.148 \\
ATHERO & $0.660^{\mathrm{a}}$ & $0.699^{\mathrm{a}}$ & $0.599^{\mathrm{b}}$ & $0.635^{\mathrm{ab}}$ & 0.021 \\
\hline
\end{tabular}

Means in the same row followed by the same superscript letter do not differ significantly by the Tukey test ( $p \leq 0.05) ;$ SEM = standard error of mean; SFA = saturated fatty acids; UFA = unsaturated fatty acids; MUFA = monounsaturated fatty acids; PUFA = polyunsaturated fatty acids; $n 6=n-6$ fatty acids; $n 3=$ $n-3$ fatty acids; $n 6: n 3=n-6$ divided by $n-3 ;$ UFA:SFA = unsaturated divided by saturated fatty acids; PUFA:SFA = polyunsaturated divided by saturated fatty acids; DFA = desirable fatty acids; AD9C16, AD9C18, ELONGASE: $\Delta 9$ desaturase Cis-9 C16 activity, $\Delta 9$-desaturase Cis-9 C18 activity, elongase enzyme activity, respectively, determined as described by Oliveira et al. (2011) using mathematical indices; ATHERO = atherogenicity index calculated in accordance with the method of Ulbricht and Southgate (1991). genetic groups (Table 2), as expected, since the other groups are not specialized for meat production and therefore have lower potential for weight gain as seen in previous studies (Issakowicz et al., 2016). Crossbred DM lambs had better DLWG and FC compared to pure MN lambs, which was not seen in the comparison between DS and SI animals. The larger difference found between DM and pure MN lambs may be associated with greater genetic distance between Morada Nova and Dorper genotypes and this effect intensified after weaning, when the amount of milk produced by the mother no longer has an effect on the performance of the lamb. Studies on Santa Inês sheep have shown recent introgression of this breed with meat producing breeds (Paiva et al., 2005), leading to an improvement in production traits (Carneiro et al., 2010) but a reduction in rusticity and heat tolerance (McManus et al., 2011) thereby explaining the lack of difference between crosses and this breed.

Higher DLWG and FC lead to a reduction in slaughter age and consequently the period that the animal remains in the feedlot, which reduces feed costs. Additionally, with advancing age at slaughter, there is a reduction in the proportion of prime cuts such as leg, shoulder, rump cap and mignon and an increase of less valuable cuts, such as the neck, as well as inguinal, visceral and kidney fats (Figure 2), leading to a lower value carcasses. 
Table 6 - Least square means of fatty acid profile $(\mathrm{g} / 100 \mathrm{~g}$ of total fatty acids) of meat from Morada Nova (MN), $1 / 2$ Dorper x $1 / 2$ Morada Nova (DM), Santa Inês (SI) and $1 / 2$ Dorper x $1 / 2$ Santa Inês (DS) lambs finished in feedlot.

\begin{tabular}{|c|c|c|c|c|c|}
\hline & DM & MN & DS & $\mathrm{SI}$ & SEM \\
\hline C10:0 & 0.197 & 0.153 & 0.197 & 0.162 & 0.014 \\
\hline C12:0 & 0.172 & 0.135 & 0.194 & 0.157 & 0.020 \\
\hline $\mathrm{C} 14: 0$ & 2.557 & 2.497 & 2.441 & 2.269 & 0.192 \\
\hline C15:0 anteiso & $0.119^{a b}$ & $0.096^{b}$ & $0.143^{a}$ & $0.098^{b}$ & 0.010 \\
\hline $\mathrm{C} 15: 0$ iso & $0.112^{\mathrm{a}}$ & $0.077^{b}$ & $0.118^{a}$ & $0.096^{\mathrm{ab}}$ & 0.007 \\
\hline C14:1c9 & 0.087 & 0.103 & 0.071 & 0.066 & 0.011 \\
\hline C15:0 & $0.274^{\mathrm{ab}}$ & $0.226^{b}$ & $0.304^{\mathrm{a}}$ & $0.247^{a b}$ & 0.017 \\
\hline $\mathrm{C} 16: 0$ iso & 0.13 & 0.097 & 0.128 & 0.11 & 0.009 \\
\hline $\mathrm{C} 16: 0$ & 23.72 & 25.57 & 22.61 & 25.24 & 1.175 \\
\hline $\mathrm{C} 17: 0$ iso & $0.356^{a}$ & $0.225^{b}$ & $0.428^{a}$ & $0.335^{\mathrm{ab}}$ & 0.029 \\
\hline C16:1c9 & 2.121 & 2.261 & 1.974 & 1.908 & 0.110 \\
\hline $\mathrm{C} 17: 0$ & $0.879^{\mathrm{ab}}$ & $0.772^{b}$ & $0.951^{a}$ & $0.853^{\mathrm{ab}}$ & 0.034 \\
\hline C17:1 & 0.409 & 0.457 & 0.416 & 0.341 & 0.032 \\
\hline C18:0 & 17.34 & 1553 & 17.76 & 18.32 & 0.926 \\
\hline C18:1trans & $1.277^{\mathrm{ab}}$ & $0.933^{b}$ & $1.721^{\mathrm{a}}$ & $1.031^{\mathrm{b}}$ & 0.147 \\
\hline C18:1c9 & 41.17 & 40.62 & 37.73 & 38.98 & 1.411 \\
\hline C18:1c11 & 1.336 & 1.387 & 1.561 & 1.498 & 0.144 \\
\hline C18:1c12 & 0.483 & 0.565 & 0.505 & 0.518 & 0.045 \\
\hline C18:1c13 & 0.326 & 0.412 & 0.409 & 0.345 & 0.038 \\
\hline C18:1t16 & 0.173 & 0.209 & 0.162 & 0.159 & 0.019 \\
\hline C18:1c15 & 0.125 & 0.128 & 0.129 & 0.105 & 0.017 \\
\hline C18:2c9c12 & $3.57^{b}$ & $4.079^{\mathrm{ab}}$ & $5.345^{\mathrm{a}}$ & $3.769^{b}$ & 0.366 \\
\hline C18:3n3 & $0.116^{\mathrm{ab}}$ & $0.093^{b}$ & $0.147^{a}$ & $0.117^{\mathrm{ab}}$ & 0.008 \\
\hline $\mathrm{C} 20: 1$ & 0.14 & 0.17 & 0.147 & 0.135 & 0.009 \\
\hline C18:2c9t11 & 0.388 & 0.321 & 0.403 & 0.321 & 0.026 \\
\hline C20:4n6 & $1.316^{\mathrm{b}}$ & $1.783^{\mathrm{ab}}$ & $2.532^{\mathrm{a}}$ & $1.679^{a b}$ & 0.258 \\
\hline C22:5 & $0.169^{b}$ & $0.223^{\mathrm{ab}}$ & $0.336^{a}$ & $0.227^{a b}$ & 0.033 \\
\hline
\end{tabular}

Only fatty acids with least square means greater than $0.05 \mathrm{~g} / 100 \mathrm{~g}$ of fat are shown. Means in the same row followed by the same superscript letter do not differ significantly by the Tukey test ( $p \leq 0.05)$; SEM: standard error of mean.

The different degree of physiological maturity of the genotypes used in this study seems to be responsible for variations in carcass composition, mainly EE content, as seen in the chemical composition of the $12^{\text {th }} \mathrm{rib}$, which is a good indicator of the animal body composition. Taylor (1985) showed that an increase in animal maturity leads to an increase in fat proportion, a decrease in bone percentage and a small change in muscle percentage. Thus, animals with higher fat content in the carcass have a higher degree of maturity, such as the Morada Nova breed, which has lower adult weight than Santa Ines and Dorper animals do, leading to a higher length of time to reach the predetermined $35 \mathrm{~kg}$ slaughter weight, approximately $75 \%$ of the adult male weight. The maturity degree may be responsible for carcass composition, since the animals were slaughtered with similar weights as determined by market demand, such as standardized carcasses and cut weights.

The best conformation and the highest leg and carcass compactness index were seen in crossbred lambs (Table 3), suggesting that these animals have improved conformation for meat production, with greater tissue deposition in more valuable regions, such as the leg. These results are consistent with Hopkins and Fogarty (1998), who stated that higher performance is expected in regions of higher commercial value in breeds specialized in meat production. The higher muscle deposition in the carcass of crossbred animals was also evident by the larger loin of these animals (Table 4), since the Longíssimus lumborum muscle has a high positive correlation with body development and can be also used to estimate the muscle amount in the carcass (Taylor, 1985).

The discriminant analysis showed that the leg compactness index was important to separate the genetic groups, which is an important variable to classify carcasses of better quality, since animals with a higher leg compactness index also have higher conformation and carcass compactness index.

In this study, there were no differences in pH24 between the groups $(p>0.05)$, also observed by Ekiz et al. (2009) in animals of different genetic groups. In general, significant variations in final meat $\mathrm{pH}$ between different genotypes are explained by depletion of muscle glycogen storage caused by stress before slaughter or the low energy supply from the diet (Hopkins and Mortimer, 2014). Here, all lambs were kept under similar conditions before slaughter, in the absence of highly intensive management and with suitable dietary plans.

Crossbred DS lambs showed better fatty acid relations and desirable fatty acids than DM animals did, resulting in a better atherogenicity index (Tables 5 and 6). This index is used to calculate the risks that food represents to human health and the lower value found in DS lambs is indicative that they have fat with a better nutritional profile, which can reduce the risk of coronary diseases.

Wood et al. (2008), in their extensive review on fat and meat quality, reported that a reduction in fat intake is desirable, especially fats rich in saturated fatty acids, and an increase in mono and poly-unsaturated fats, to reduce the risks of obesity, cancer and cardiovascular diseases. Thus, higher amounts of linoleic acid (C18:2C9C12) and arachidonic acid (C20:4n6) and, consequently, larger amounts of PUFAs and higher PUFA: SFA ratio of the meat from DS animals in relation to DM animals show better quality for human consumption.

Increasing slaughter age and fat content in the carcass affected the lipid profile. The development of adipose tissue during the animal growth is primarily due to hyperplasia, and then by hypertrophy of adipocytes. In younger animals, adipocytes are smaller, which results in a higher relationship between the cell membrane (which is rich in PUFA particularly omega-3 and omega-6 (Brand et al., 2010)) and the content, increasing the proportion of unsaturated fatty acids. This justifies the higher levels of omega- 3 and omega- 6 and, consequently, a higher proportion of polyunsaturated fatty ac- 
ids found in DS animals compared to DM lambs. These findings suggest that deposition of some fatty acids depend on the age and genotype of the animal, where the genotype effect is due to the capacity of each genotype to deposit fat.

The fatty acids observed in higher quantities were oleic (C18:1C9) indicating the potential of lamb meat as a source of desirable fatty acid, followed by palmitic $(\mathrm{C} 16: 0)$ and stearic $(\mathrm{C} 18: 0)$. Although stearic acid is present in high amounts, it does not seem to affect cholesterol levels in humans, because it is converted in to oleic acid (C18:1) inside the organism (Bonanome and Grundy, 1988). On the other hand, palmitic and myristic acids (C14: 0) are potential causes of cardiovascular disease as they increase cholesterol concentration (Daley et al., 2010). Of these two acids, myristic acid is more undesirable; however, it is not a major concern because it represented about $2 \%$ in all genetic groups in the present study.

Regarding the amount of essential fatty acids (omega-6 and omega-3), meat of DS lambs showed nearly twice as much the amount found in DM animals, where the greater quantity of omega- 6 was boosted by the increase in linoleic and arachidonic acids, indicating once again the differentiated fat quality in meat from these animals. However, a balance in amounts of $n-6$ and n-3 fatty acids is desirable (around 10:1) according to the recommendations of the Institute of Medicine (2002), similar to that observed in this study. High intake of omega- 6 , associated with low omega- 3 consumption, causes physiological changes that trigger pro-inflammatory and pro-thrombotic status with increased vasospasm, vasoconstriction and blood viscosity, favoring the onset of coronary heart diseases (Patterson et al., 2012). Therefore, when the objective is to obtain lean meat, with improved nutritional profile to reduce risks of cardiovascular diseases, the use of breeds and crosses that reduce the slaughter age of animal, such as the $1 / 2$ Dorper $\times 1 / 2$ Santa Inês crossbred, is an interesting alternative.

\section{Acknowledgments}

São Paulo Research Foundation (FAPESP - Process 2012/23780-9), Brazilian National Council for Scientific and Technological Development (CNPQ - Process 159738/2012-1) and Coordination for the Improvement of Higher Level Personnel (CAPES) - Program of Academic Excellence (PROEX) for the scholarship.

\section{References}

Association of Official Analytical Chemists [AOAC]. 1995. Official Methods of Analysis of the AOAC. 16ed. AOAC International, Gaithersburg, MD, USA.

Bonanome, A.; Grundy, S.M. 1988. Effect of dietary stearic acid on plasma cholesterol and lipoprotein levels. The New England Journal of Medicine 318: 1244-1248.
Brand, A.; Bauer, N.; Hallott, A.; Goldbaum, O.; Ghebremeskel, K.; Reinfen, R.; Richter-Landsberg, C. 2010. Membrane lipid modification by polyunsaturated fatty acids sensitizes oligodendroglial OLN-93 cells against oxidative stress and promotes up-regulation of heme oxygenase-1 (HSP32). Journal of Neurochemistry 113: 465-476.

Carneiro, H.; Louvandini, H.; Paiva, S.R.; Macedo, F.; Mernies, B.; McManus, C. 2010. Morphological characterization of sheep breeds in Brazil, Uruguay and Colombia. Small Ruminant Research 94: 1-8.

Daley, C.A.; Abbott, A.; Doyle, P.S.; Nader, G.A.; Larson, S. 2010. A review of fatty acid profiles and antioxidant content in grassfed and grain-fed beef. Nutrition Journal 9: 10.

De Smet, S.; Raes, K.; Demeyer, D. 2004. Meat fatty acid composition as affected by fatness and genetic factors: a review. Animal Research 53: 81-98.

Ekiz, B.; Yilmaz, A.; Ozcan, M.; Kaptan, C.; Hanoglu, H.; Erdogan, I.; Yalcintan, H. 2009. Carcass measurements and meat quality of Turkish Merino, Ramlic, Kivircik, Chios and Imroz lambs raised under an intensive production system. Meat Science 82: 64-70.

Folch, J.; Lees, M.; Stanley, G. 1957. A simple method for the isolation and purification of total lipids from animal tissues. Journal of Biological Chemistry 226: 497-509.

Gomes, E.F.; Louvandini, H.; Dallago, B.; Canozzi, M.E.A.; Melo, C.B.; Moreno-Bernal, F.E.; McManus, C. 2013. Productivity in ewes of different genetic groups and body sizes. Journal of Animal Science Advances 3: 243-255.

Hankins, O.G.; Howe, P.E. 1946. Estimation of the Composition of Beef Carcasses and Cuts. USDA, Washington, DC, USA. (Technical Bulletin, 926).

Hara, A.; Radin, N. 1978. Lipid extraction of tissues with a lowtoxicity solvent. Analytical Biochemistry 90: 420-426.

Hopkins, D.L.; Fogarty, N.M. 1998. Diverse lamb genotypes- 2. Meat $\mathrm{pH}$, colour and tenderness. Meat Science 49: 477-488.

Hopkins, D.L.; Mortimer, S.I. 2014. Effect of genotype, gender and age on sheep meat quality and a case study illustrating integration of knowledge. Meat Science 98: 544-555.

Institute of Medicine. 2002. Dietary Reference Intakes (DRIs) for Energy, Carbohydrate, Fiber, Fat, Fatty Acids, Cholesterol, Protein, and Amino Acids. National Academies Press, Washington, DC, USA.

Issakowicz, J.; Bueno, M.S.; Sampaio, A.C.K.; Duarte, K.M.R. 2013. Effect of concentrate level and live yeast (Saccharomyces cerevisiae) supplementation on Texel lamb performance and carcass characteristics. Livestock Science 155: 44-52.

Issakowicz, J.; Issakowicz, A.C.K.S.; Bueno, M.B.; Costa, R.L.D.; Katiki, L.M.; Geraldo, A.T.; Abdalla, A.L.; McManus, C.; Louvandini, H. 2016. Parasitic infection, reproductive and productive performance from Santa Inês and Morada Nova ewes. Small Ruminant Research 136: 96-103.

Kariuki, C.M.; Ilatsia, E.; Kosgey, I.; Kahi, A. 2010. Direct and maternal (co) variance components, genetic parameters and annual trends for growth traits of Dorper sheep in semi-arid Kenya. Tropical Animal Health and Production 42: 473-481.

Kosgey, I.S.; Rowlands, G.J.; van Arendonk, J.A.M.; Baker, R.L. 2008. Small ruminant production in smallholder and pastoral/ extensive farming systems in Kenya. Small Ruminant Research 77: $11-24$. 
Landim, A.V.; Castanheira, M.; Fioravanti, M.C.; Pacheco, A.; Cardoso, M.T.; Louvandini, H.; McManus, C. 2011. Physical, chemical and sensorial parameters for lambs of different groups, slaughtered at different weights. Tropical Animal Health and Production 43: 1089-1096.

McManus, C.; Hermuche, P.; Paiva, S.R.; Melo, C.B.; Mendes, C.Q. 2014. Geographical distribution of sheep breeds in Brazil and their relationship with climatic and environmental factors as risk classification for conservation. Brazilian Journal of Science and Technology 1: 1-15.

McManus, C.; Louvandini, H.; Paim, T.P.; Martins, R.F.S.; Barcellos, J.O.J.; Cardoso, C.C.; Guimarães, R.F.; Santana, A.O. 2011. The challenge of sheep farming in the tropics: aspects related to heat tolerance. Revista Brasileira de Zootecnia 40: 107-120.

McManus, C.; Paiva, S.R.; Araújo, R.O. 2010. Genetics and breeding of sheep in Brazil. Revista Brasileira de Zootecnia 39: 236-246.

Milne, C. 2000. The history of the Dorper sheep. Small Ruminant Research 36: 99-102.

Paiva, S.R.; Silvério, V.C.; Faria, D.A.; Egito, A.A.; McManus, C.; Mariante, A.S.; Castro, S.T.R.; Albuquerque, M.S.M.; Dergam, J.A. 2005. Origin of the main locally adapted sheep breeds of Brazil: a RFLP-PCR molecular analysis. Archivos de Zootecnia 54: 395-399.
Patterson, E.; Wall, R.; Fitzgerald, G.F.; Ross, R.P.; Stanton, C. 2012. Health implications of high dietary omega- 6 polyunsaturated fatty acids. Journal of Nutrition and Metabolism 2012: article 539426.

Santos, C.L.; Olalquiaga Pérez, J.R.; Muniz, J.A.; Geraseev, L.C.; Siqueira, E.R. 2001. Relative Development of the Bone, Muscular and Fat Tissues of Joints of the Carcass of Santa Ines Lambs. Revista Brasileira de Zootecnia 30: 487-492 (in Portuguese, with abstract in English).

Taylor, C.S. 1985. Use of genetic size scaling in evaluation of animal growth. Journal of Animal Science 61: 119-141.

Teklebrhan, T.; Urge, M.; Mekasha, Y.; Baissa, M. 2014. Preweaning growth performance of crossbred lambs (Dorper $\times$ indigenous sheep breeds) under semi-intensive management in eastern Ethiopia. Tropical Animal Health and Production 46: 455-460.

Ulbricht, T.L.; Southgate, D.A. 1991. Coronary heart disease: seven dietary factors. The Lancet 338: 985-992.

Wood, J.D.; Enser, M.; Fisher, A.V.; Nute, G.R.; Sheard, P.R.; Richardson, R.I.; Hughes, S.I.; Whittington, F.M. 2008. Fat deposition, fatty acid composition and meat quality: a review. Meat Science 78: 343-358. 